\title{
Evaluation of extracts from Coccoloba mollis using the Salmonella/microsome system and in vivo tests
}

\author{
Marcela Stefanini Tsuboy ${ }^{1}$, Juliana Cristina Marcarini ${ }^{1}$, Dalva Trevisan Ferreira ${ }^{2}$, \\ Elisa Raquel Anastácio Ferraz ${ }^{3}$, Farah Maria Drumond Chequer ${ }^{3}$, Danielle Palma de Oliveira ${ }^{3}$, \\ Lúcia Regina Ribeiro ${ }^{4}$ and Mário Sérgio Mantovani ${ }^{1}$ \\ ${ }^{1}$ Departamento de Biologia Geral, Universidade Estadual de Londrina, Londrina, PR, Brazil. \\ ${ }^{2}$ Departamento de Química, Universidade Estadual de Londrina, Londrina, PR, Brazil. \\ ${ }^{3}$ Departamento de Análises Clínicas, Toxicológicas e Bromatológicas, Faculdade de Ciências \\ Farmacêuticas de Ribeirão Preto, Universidade de São Paulo, Ribeirão Preto, SP, Brazil. \\ ${ }^{4}$ Instituto de Biociências, Universidade Estadual Paulista "Júlio de Mesquita Filho", Rio Claro, SP, Brazil.
}

\begin{abstract}
The common everyday use of medicinal plants is an ancient, and still very widespread practice, whereby the need for studies on their possible toxicity and mutagenic properties. The species Coccoloba mollis has been much used in phytotherapy, mainly in cases involving loss of memory and stress. In order to investigate its genotoxic and mutagenic potential, ethanolic extracts from the leaves and roots underwent Salmonella/microsome assaying (TA98 and TA100 strains, with and without exogenous metabolism - S9), besides comet and micronucleus tests in vivo. There was no significant increase in the number of revertants/plate of Salmonella strains in any of the analyzed root-extract concentrations, although the extract itself was extremely toxic to the Salmonella TA98 strain in the tests carried out with S9 (doses varying from 0.005 to $0.5 \mu \mathrm{g} /$ plate). On the other hand, the leaf-extract induced mutations in the TA98 strain in the absence of S9 in the highest concentration evaluated, although at very low mutagenic potency $(0.004 \mathrm{rev} / \mu \mathrm{g})$. Furthermore, there was no statistically significant increase in the number of comets and micronuclei, in treatments involving Swiss mice. It was obvious that extracts of Coccoloba mollis, under the described experimental conditions, are not mutagenic.
\end{abstract}

Key words: medicinal plants, Coccoloba mollis, Ames test, in vivo comet assay, in vivo micronucleus assay, Polygonaceae.

Received: June 23, 2009; Accepted: February 1, 2010.

\section{Introduction}

The use of plants for medicinal purposes is one of the oldest forms of medical practice. Besides this practice continuing to be important in primary health care of the less fortunate population in developing countries, the procurement of medications of natural origin in developed countries has increased considerably in the last decades (WHO, 2000). Therefore, special attention should be given to the evaluation of the safety, efficacy and quality of natural products, which includes the evaluation of natural therapeutic agents for genotoxicity/mutagenicity as recommended by national and international regulatory agencies (CNS, 1997; OECD, 2001).

Although there is scientific endorsement of the numerous benefits arising from medicinal plants, their general

Send Correspondence to Mário S. Mantovani. Departamento de Biologia Geral, Universidade Estadual de Londrina, Campus Universitário, Caixa Postal 6001, 86051-990 Londrina, PR, Brazil. E-mail: biomsm@uel.br. use should be viewed with caution. Adverse effects can develop due to intrinsic toxicity, adulteration, substitution, contamination, the erroneous identification of plant material, the lack of inspection, and the interaction with other drugs (Rates, 2001; Zhou et al., 2004).

The species Coccoloba mollis Casaretto (Polygonaceae) is commonly used for phytotherapeutic purposes under the name of "Erva da memória" or the memory herb. The popular use of this plant has been reported as beneficial in cases of memory loss, stress, insomnia, anemia, diminishing eyesight and sexual impotency. The product is manually prepared in extract form with alcohol from the roots and leaves of the plant. Once prepared, it is kept in the dark for about 15 days. Users are recommended to ingest 10 drops of the tincture diluted in water, two or three times a day. The species, popularly known as folha-de-bôlo or falso-novateiro, occurs in shrublands and semideciduous forests in the Parana River basin, in the center-southern region of Brazil (Lorenzi, 2002). Species of the genus Coccoloba have been used in astringent form, in 
the treatment of fever, diarrhea, gonorrhea, hemorrhoids, menstruation problems and uterine hemorrhage (Mors et al., 2000; Cota et al., 2003). Nevertheless to date no information is available in the scientific literature, as to the biological effects on in vitro and in vivo systems. On considering the genus Coccoloba, and the importance of scientific evaluation of medicinal plants of common use|, the aim was to determine the genotoxicity/mutagenicity of leaf and root ethanolic extracts from Coccoloba mollis by using Salmonella/microsome assaying (Ames test), as well as in vivo \pm and micronucleus tests.

\section{Materials and Methods}

\section{Extracts of Coccoloba mollis}

A dried, powdered material (from both leaves and roots) was extracted with $95 \%$ ethanol at room temperature, the solvent then being removed under vacuum to yield $40 \mathrm{~g}$ of root extract (RE) and $85 \mathrm{~g}$ of leaf extract (LE). The leaf material underwent successive fractional partitioning by ethyl acetate. These fractions $(30 \mathrm{~g})$ were then chromatographed on a silica gel (174 g) column using increasing polarity solvents ( $n$-hexane, dichloromethane and ethyl acetate). The root extract also underwent successive fractional partitioning by $n$-hexane and ethyl acetate. The hexane soluble fraction $(4,5 \mathrm{~g})$ was chromatographed on a silica gel $(163,66 \mathrm{~g})$ column using increasing polarity solvents ( $n$-hexane, dichloromethane, ethyl acetate). The major extract compounds, identified by spectroscopy (NMR, ${ }^{1} \mathrm{H} /{ }^{13} \mathrm{C}$, CG-MS, IV), were a mixture of long chain hydrocarbons, carboxyl esters and 3-taraxerone (a triterpene) in the leaf extract, and two anthraquinones (emodin and physcion) in the root. The plants collected were identified by Ana Odete Santos Vieira, PhD from the Department of Animal and Vegetal Biology of the Universidade Estadual de Londrina, UEL. A voucher specimen was deposited under number Barros, I B 001.

In the Salmonella/microsome assay, the extracts were resuspended in dimethylsulfoxide (DMSO), using test concentration limits, as recommended in the literature (Mortelmans and Zeiger, 2000; SBMCTA, 2004). Based on this recommendation, pure substances or extracts should be tested either at a maximal concentration of $5 \mathrm{mg} /$ plate, or up to their respective solubility limit. Thus, the root extract (RE) was tested at a concentration of $5 \mathrm{mg} /$ plate, whereas the leaf extract (LE) was tested at a lower maximal concentration of $3 \mathrm{mg} / \mathrm{plate}$, due to limited solubility. Initially, assaying was carried out with five concentrations based on a logarithmic scale, in order to determine the range of mutagenic concentrations, if present. Based on this preliminary assay, new test concentrations were chosen

Prior to administration to animals, both extracts (LE and RE) were dissolved in DMSO and PBS (phosphate buffer saline), the DMSO concentration not exceeding $10 \%$ of the total volume of the mother solution in preparation.
They were then filtered with $0.22 \mu \mathrm{m}$ porosity disposable filters (Millex ${ }^{\circledR}$ - Millipore), and subsequently sterilized. Administration was via gavage.

\section{Experimental animals}

Fifty-six male Swiss mice (Mus musculus), each weighing approximately $30 \mathrm{~g}$, were distributed into control and experimental groups, consisting of seven animals per treatment, eight groups all told. They were kept in the Animal House for Small Mammals of the Department of General Biology, Biological Sciences Center, Londrina State University (CCB/UEL), under controlled conditions as to temperature $\left(22 \pm 2{ }^{\circ} \mathrm{C}\right)$, humidity $(55 \pm 10 \%)$ and photoperiod $(12 \mathrm{~h})$. The animals were given solid rations and water ad libitum during the entire experimental period.

\section{Experimental protocols and procedures for Salmonella/microsome assaying (Ames test)}

The protocol employed was that with pre-incubation, according to Maron and Ames (1983) and Mortelmans and Zeiger (2000). Briefly, $100 \mu \mathrm{L}$ of culture from each strain $\left(10^{9}\right.$ cells $\left./ \mathrm{mL}\right)$ were placed in previously sterilized tubes, where upon $100 \mu \mathrm{L}$ of each extract solution at different concentrations were added, together with $500 \mu \mathrm{L}$ of $0.2 \mathrm{M}$ phosphate buffer for the assay in the absence of metabolic activation, or the same volume of the S9 mixture with metabolic activation. Tube contents were mixed and incubated at $37^{\circ} \mathrm{C}$ for $30 \mathrm{~min} .2 .0 \mathrm{~mL}$ of surface agar were added, the tubes were mixed, and the mixture was poured into a Petri dish with $20 \mathrm{~mL}$ of minimum agar. The plates were incubated upside down for $66 \mathrm{~h}$ at $37^{\circ} \mathrm{C}( \pm 0.5)$. The test was performed in triplicate. For this study, the strains TA98 and TA100 were chosen, which detect the majority of mutagenic compounds, as the first detects frameshift mutations, whereas the second identifies base-pair substitutions (Maron and Ames, 1983).

DMSO was used as negative control. As positive control in the tests without S9, 4-nitroquinoline-1-oxide (4NQO; CAS number 56-57-5), was used at a concentration of $0.5 \mu \mathrm{g} /$ plate. For the tests carried out in the presence of S9, the positive control was 2-aminoanthracene (2AA; CAS number 613-13-8) at a concentration of $2.5 \mu \mathrm{g} /$ plate.

The background was carefully examined to check toxicity. Samples were considered toxic when a thinning of the background lawn was observed. This may be accompanied by a decrease in the number of revertants, the absence of a background lawn or presence of pinpoint non-revertant colonies, generally in conjunction with an absence of a background lawn according to Mortelmans and Zeiger (2000). The colonies were counted manually. Samples were considered positive when ANOVA and dose response were both significant when using the Bernstein model (Bernstein et al., 1982; Umbuzeiro and Vargas, 2003). The results were submitted to statistical analysis using Salanal, 
a program developed by Integrated Laboratory Systems, Research Triangle Park, N.C., USA.

\section{Experimental protocols and procedures for in vivo comet and micronucleus assays}

The experimental animals were distributed into eight groups: (1) negative control; (2) positive control (cyclophosphamide; CAS number $6055-19-2 ; 50 \mathrm{mg} / \mathrm{kg}$ body weight); (3/4) [LE1]/[RE1] (dose 1 of LE and RE - $6.6 \mathrm{x}$ $10^{-3} \mathrm{mg} / \mathrm{kg}$ b.w.); (5/6) [LE 2]/[RE 2] (dose 2 of LE and RE $-6.6 \times 10^{-2} \mathrm{mg} / \mathrm{kg} \mathrm{b.w}$.); and (7/8) [LE 3]/[RE 3] (dose 3 of $\mathrm{LE}$ and RE - $6.6 \times 10^{-1} \mathrm{mg} / \mathrm{kg}$ b.w.).

In group 1 (negative control), PBS was administered via gavage and intraperitoneally, whereas in group 2 (positive control), PBS was via gavage and cyclophosphamide $(50 \mathrm{mg} / \mathrm{kg})$ intraperitoneally. In animals pertaining to the groups for determination of extract genotoxicity (3 to 8), LE or RE were ingested and PBS administered intraperitoneally.

Comet testing was according to Tice et al. (2000). $20 \mu \mathrm{L}$ of peripheral blood was withdrawn from each animal by caudal vein puncturing, $24 \mathrm{~h}$ after treatment application. This material was carefully mixed with $120 \mu \mathrm{L}$ of low melting-point agarose (LMP, $0.5 \%$ ) at $37{ }^{\circ} \mathrm{C}$ and deposited on pre-gelatinized slides. The slides were then placed in lysis solution for at least $1 \mathrm{~h}$. After denaturation $(20 \mathrm{~min})$ and alkaline electrophoresis $(25 \mathrm{~V}, 300 \mathrm{~mA}, 20 \mathrm{~min})$, the slides were neutralized, fixed and kept refrigerated until analysis., when they were stained with ethidium bromide and examined visually using a fluorescence microscope (excitation filter of 420-490 nm and emission filter of $520 \mathrm{~nm}$ ), according to Kobayashi et al. (1995). One hundred cells were analyzed per slide and per animal. The comets were classified as: class 0 - nucleoids with no tail; class 1 - nucleoids with a tail shorter than the diameter of the nucleoid itself; class 2 nucleoids with a tail 1 to 2 times the diameter of the nucleoid; and class 3 - nucleoids with a tail more than twice the diameter.

In the micronucleus test, a few drops of blood drawn from the caudal vein were placed on slides pre-stained with acridine orange, and immediately cover-slipped (Hayashi et al., 1990). This procedure was performed $48 \mathrm{~h}$ after treatment administration (in accordance with the results of positive controls in our laboratory, and coinciding with the highest peak in micronucleus induction). A total of 2000 reticulocytes were examined per slide per animal by fluorescence-microscopy.

The data obtained in in vivo experiments were submitted to non-parametric analysis of variance (KruskallWallis), followed by Dunn's test, with $\alpha=0.05$, using GraphPad Instat ${ }^{\circledR}$, version 3.02 software.

\section{Results}

In the Ames test, the results indicated that only LE had a mutagenic effect, albeit at very low potency $(0.004$ $\mathrm{rev} / \mu \mathrm{g}$ ), whereas under other test conditions, mutagenicity was not observed (Table 1). As to the root extract (RE), mutagenic potency was not noted under any of the conditions tested, although in the TA98 strain in the presence of S9, this extract was highly toxic for Salmonella at all the concentrations tested $(\mathrm{p} \sim 1)$ (Table 2).

The results obtained in the comet and micronucleus tests suggest that the treatment of animals with the leaf and root extracts from Coccoloba mollis, and under the above described experimental conditions, was not genotoxic.

The findings of the comet assay are presented in Figure 1. A statistically significant increase in DNA damage only occurred in those animals treated with the DNA damage-inducing agent cyclophosphamide. The same occurred in the determination of micronuclei in reticulocytes. A statistically significant increase in the frequency of micronuclei was seen only in animals treated with cyclophosphamide (Table 3).

Table 1 - Data obtained in the evaluation of the mutagenicity of leaf extract (LE) from C. mollis with TA98 and TA100 Salmonella typhimurium strains concurrent with or without metabolic activation (S9).

\begin{tabular}{lcclcc}
\hline Dose $(\mu \mathrm{g} /$ plate) & TA98 - S9 & TA 98 + S9 & Dose $(\mu \mathrm{g} /$ plate $)$ & TA100 - S9 & TA 100 + S9 \\
\hline 0 & $18 \pm 3.00$ & $33.33 \pm 6.11$ & 0 & $139 \pm 3.00$ & $102.33 \pm 2.89$ \\
4NQO (TA98 - S9) or & $520 \pm 105.83^{*}$ & $700 \pm 100.00^{*}$ & 4NQO (TA98 - S9) or & $1030 \pm 62.44^{*}$ & $890 \pm 85.44$ \\
2AA (TA 98+ S9) & & 2 AA (TA 98+ S9) & & $140.33 \pm 5.03$ & $101.67 \pm 6.66$ \\
0.3 & $16.67 \pm 1.53$ & $32 \pm 2.65$ & 3 & $142 \pm 9.54$ & $107.33 \pm 4.51$ \\
3 & $17.67 \pm 1.53$ & $34 \pm 3.61$ & 30 & $138.33 \pm 5.86$ & $104.67 \pm 8.02$ \\
30 & $19 \pm 2.00$ & $33.67 \pm 4.16$ & 300 & $140 \pm 11.36$ & $116.33 \pm 15.37$ \\
300 & $23.67 \pm 1.15$ & $35.67 \pm 2.08$ & 1000 & $148.67 \pm 16.26$ & $114.33 \pm 9.71$ \\
3000 & $31.33 \pm 4.16^{*}$ & $41 \pm 5.57$ & 2000 & &
\end{tabular}

*Significant at $5 \%$.

4NQO $(0.5 \mu \mathrm{g} /$ plate $)=$ positive control in tests without $\mathrm{S} 9$.

$2 \mathrm{AA}(2.5 \mu \mathrm{g} /$ plate $)=$ positive control in tests with S9. 
Table 2 - Data obtained in the evaluation of the mutagenicity of root extract (RE) from C. mollis with TA98 and TA100 Salmonella typhimurium strains concurrent with or without metabolic activation (S9).

\begin{tabular}{lccclcc}
\hline Dose $(\mu \mathrm{g} /$ plate $)$ & TA98- S9 & Dose $(\mu \mathrm{g} / \mathrm{plate})$ & TA $98+\mathrm{S} 9$ & Dose $(\mu \mathrm{g} / \mathrm{plate})$ & TA100 - S9 & TA 100 + S9 \\
\hline 0 & $24.33 \pm 4.51$ & 0 & $33.33 \pm 6.11$ & 0 & $139 \pm 3.00$ & $102.33 \pm 2.89$ \\
$4 \mathrm{NQO}$ & $520 \pm 105.83^{*}$ & $2 \mathrm{AA}$ & $700 \pm 100.00^{*}$ & 4NQO (TA100 - S9) or & $1030 \pm 62.44 *$ & $890 \pm 85.44$ \\
& & & & 2 AA (TA100+ S9) & $139.33 \pm 4.51$ & $108 \pm 5.57$ \\
5 & $19 \pm 2.65$ & 0.005 & $\mathrm{~T}$ & 5 & $142 \pm 4.36$ & $116.67 \pm 7.09$ \\
50 & $17.67 \pm 2.08$ & 0.05 & $\mathrm{~T}$ & 50 & $144 \pm 6.0$ & $117 \pm 7.0$ \\
500 & $21.67 \pm 2.52$ & 0.1 & $\mathrm{~T}$ & 100 & $140.33 \pm 4.51$ & $116 \pm 9.85$ \\
3000 & $19.67 \pm 2.08$ & 0.25 & $\mathrm{~T}$ & 200 & $151 \pm 9.54$ & $114 \pm 8.89$ \\
4000 & $21.33 \pm 1.53$ & 0.5 & $\mathrm{~T}$ & 300 & &
\end{tabular}

$\mathrm{T}=$ toxic.

*Significant at $5 \%$.

4NQO $(0.5 \mu \mathrm{g} /$ plate $)=$ positive control in tests without S9.

$2 \mathrm{AA}(2.5 \mu \mathrm{g} /$ plate $)=$ positive control in tests with S9.

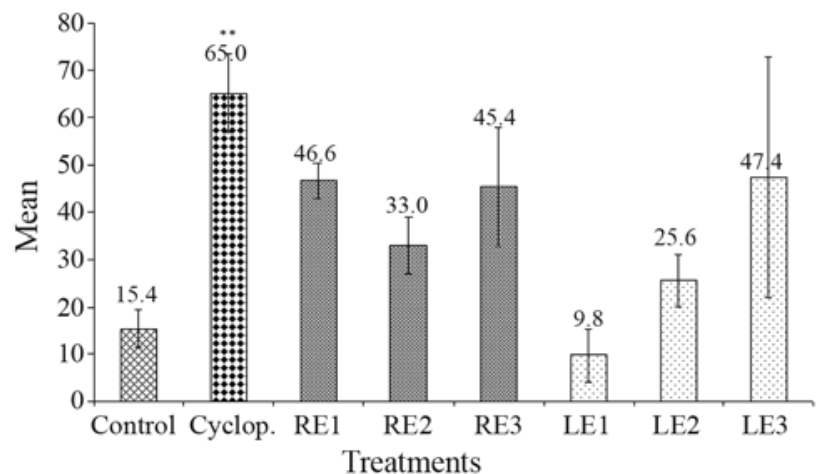

Figure 1 - Mean score of comets observed in peripheral blood erythrocytes of male Swiss mice $24 \mathrm{~h}$ after treatment with extracts from C. mollis. Control: PBS; Cyclop.: cyclophosphamide - $50 \mathrm{mg} / \mathrm{kg}$; RE1: $6.6 \mathrm{x}$ $10^{-3} \mathrm{mg} / \mathrm{kg}$; RE2: $6.6 \times 10^{-2} \mathrm{mg} / \mathrm{kg}$; RE3: $6.6 \times 10^{-1} \mathrm{mg} / \mathrm{kg}$; LE1: $6.6 \times$ $10^{-3} \mathrm{mg} / \mathrm{kg}$; LE2: $6.6 \times 10^{-2} \mathrm{mg} / \mathrm{kg}$; LE3: $6.6 \times 10^{-1} \mathrm{mg} / \mathrm{kg}$. RE $=$ root ethanolic extract from $C$. mollis; $\mathrm{LE}=$ leaf ethanolic extract from $C$. mollis. ${ }^{* *} \mathrm{p}<0.01$.

A dose-response relationship could be established for the induction of DNA damage in comet assay by LE $(r=0.939)$, but this was not evident in groups treated with $\mathrm{RE}$ with regard to the data on genotoxicty in both assays. In micronucleus test, the animals treated with LE2 and RE2 $\left(6.6 \times 10^{-2} \mathrm{mg} / \mathrm{kg} \mathrm{b} . \mathrm{w}\right)$ showed a higher micronucleus frequency than with LE3 and RE3 $\left(6.6 \times 10^{-1} \mathrm{mg} / \mathrm{kg} \mathrm{b} . \mathrm{w}\right)$, which could be indicative of extract cytotoxicity at this dose.

\section{Discussion}

Interest in phytotherapy is generally motivated by its traditional use and natural origin. Although many beneficial biological activities have been scientifically corroborated, caution is called for in the public use of medicinal plants. Although most phytotherapeutic products are considered safe if used at the recommended doses, untoward
Table 3 - Evaluation of genotoxicity of extracts from C. mollis, $48 \mathrm{~h}$ after treatment of the animals. Number of experimental animals, total amount of cells analyzed, total number of MNRETs and frequency of micronuclei observed.

\begin{tabular}{lcccc}
\hline Treatment & $\mathrm{n}$ & $\begin{array}{c}\text { Total of ana- } \\
\text { lyzed cells* }\end{array}$ & $\begin{array}{c}\text { Total of cells } \\
\text { with MN } \\
\text { (MNRETs) }\end{array}$ & $\begin{array}{c}\text { fi MN mean } \\
\pm \mathrm{SD}\end{array}$ \\
\hline control & 7 & 10.000 & 37 & $7.4 \pm 2.88$ \\
cyclophosphamide & 7 & 8.000 & 132 & $33.0 \pm 5.29^{* *}$ \\
RE1 & 7 & 14.000 & 66 & $9.42 \pm 3.73$ \\
RE2 & 7 & 10.000 & 67 & $13.4 \pm 7.23$ \\
RE3 & 7 & 14.000 & 82 & $11.71 \pm 6.1$ \\
LE1 & 7 & 14.000 & 82 & $11.71 \pm 3.49$ \\
LE2 & 7 & 14.000 & 126 & $18.0 \pm 7.07$ \\
LE3 & 7 & 14.000 & 88 & $12.57 \pm 5.85$ \\
\hline
\end{tabular}

Cyclophosphamide $50 \mathrm{mg} / \mathrm{kg}$.

[LE1]/[RE1] (6.6 x 10 $0^{-3} \mathrm{mg} / \mathrm{kg}$ b.w. of LE or RE); [LE 2]/[RE 2] (6.6 x $10^{-2} \mathrm{mg} / \mathrm{kg}$ b.w. of LE or RE); [LE 3]/[RE 3] $\left(6.6 \times 10^{-1} \mathrm{mg} / \mathrm{kg}\right.$ b.w. of LE or RE).

* Variable number through the loss of material and not the death of animals during the experiment.

$* * \mathrm{p}<0.01$.

effects can occur (Phillipson, 2007). Therefore, genotoxicity/mutagenicity tests, such as those employed in the present study, are important on evaluating safety and efficacy in natural products (Bast et al., 2002). In vivo tests and the Salmonella/microsome assay are the most frequently used and recommended by regulatory agencies for determining genetic risk (FDA, 1997; OECD, 2001), since they take into account factors regarding in vivo metabolism, pharmacokinetics and DNA repair processes (Krishna and Hayashi, 2000) and since the Salmonella/microsome assay has a high predictive value for carcinogenicity in rodents when a mutagenic response is obtained (Mortelmans and Zeiger, 2000). 
A preliminary analysis of the extracts of $C$. mollis by the Salmonella/microsome system shows that they are not mutagenic, except at the highest concentration of the leaf extract (LE) tested in strain TA98, and in the absence of metabolism. Thus, under these conditions this extract possibly induces a frameshift mutation, albeit at a very low level, as this is the type of mutation detected by the TA98 strain. Furthermore, and under the same assaying conditions, it was concluded that toxicity in the root extract (RE) is greater than in the leaf (LE), due the high toxicity displayed in the TA98 strain, in the presence of metabolism. These findings are in accordance with additional data on cytotoxicity from our laboratory, where RE was shown to be more toxic than LE against HTC cells (proficient in drug metabolism) (data not shown). Thus, the biotransformation of compounds present in RE appears to be important in their in vitro toxicity. Although comet formation (DNA damage) and the frequency of micronucleated reticulocytes (MNRETs) were increased in animals treated with LE and $\mathrm{RE}$, these were not statistically significant.

The use of C. mollis as both a memory modulator and tranquilizer appears to have a certain scientific base. There are reports on the tranquilizing efficacy of plant extracts from the family Polygonaceae (Gosh et al., 2002), besides the protective action of emodin (one of the anthraquinones found in RE) against cerebral disturbances (Gu et al., 2000) and in recuperating memory (Lu et al., 2007), although little is still known about the genotoxic/mutagenic activities of the anthraquinones, especially in vivo. Mueller and colleagues have attributed genotoxicity to emodin (Mueller et al. 1998,1999; Mueller and Stopper 1999), whereas others suggest that it is antimutagenic (Sun et al. 2000; Lee et al. 2005). Based on studies by Mueller, emodin-induced mutagenicity can be explained by either the formation of 2-hydroxyemodine via CYP1A2 and CYP2B or the inhibition of topoisomerase II, due to the capacity of emodin, with its planar structure, to intercalate DNA. Mutagenicity in the TA1537 strain was shown when investigating the possible mutagenic effects of anthraquinones and their metabolites on different strains of Salmonella typhimurium (Tikkanen et al., 1983; Masuda and Ueno 1984; Masuda et al., 1985; Murakami et al., 1987; Westendorf et al., 1990; Krivobok et al., 1992). Although emodin and physcion showed mutagenicity in strain TA1537 of Salmonella after metabolism, these anthraquinones were not mutagenic in strains TA100, TA98 and TA2638 either in the absence or presence of metabolism (Krivobok et al., 1992; Mueller et al., 1999; Lee et al., 2005).

Although many mutagenicity studies in vitro showed a positive response, a long term study carried out by the $\mathrm{Na}$ tional Toxicological Program (NTP) of the National Cancer Institute in the U.S. concluded that there was no evidence of emodin possessing carcinogenic activity in male F344/N rats and female B6C3F mice (NTP, 2001). Mengs et al. (1997) also did not observe any genotoxic or cytotoxic effects following a single administration of a limited dose of emodin ( $2 \mathrm{mg} / \mathrm{kg}$ b.wt.) in bone-marrow cells of NMRI mice, thus reinforcing the importance of studies in diverse test systems to obtain more reliable conclusions. In vivo, the biotransformation of 1,8 dihydroxyanthraquinones (as emodin and physcion) appears to occur in intestinal epithelial and hepatic cells (Mueller et al., 1998), where the biotransformation of emodin is mediated by $\mathrm{P} 450$ cytochrome enzymes (Tanaka et al., 1987; Go et al., 2007). Longo et al. (2000), on studying the effects of various anthraquinones on metabolic enzymes in the liver and intestine of rats, noted that the 1,8 dihydroxyanthraquinones show the weakest induction of CYP1A2, this induction being significant only in the liver. This observation, together with the possibility that the constituents of the extracts or of their metabolites are free of mutagenic effect or are excreted before causing damage, can explain in part the absence of genotoxicity/mutagenicity effects in vivo. On the other hand, it is difficult to state or even suggest a reason for this, mainly as regards LE, since little is still known about the exact composition of this extract. Phytochemical screening using pharmacognostic methodology has revealed the presence of flavonoids and tannins in leaves and roots, whereas results were negative for alkaloids, coumarins, saponins and simple phenolics (Barros et al., 2007, 2008).

Leaf extract from Coccoloba mollis analyzed by Oliveira et al. (2008), although extracted with different methods, also presented terpenes in its composition (simiarenol and trans-phytol), besides two phytosteroids (sitostenone and sitosterol). Sitosterol, in its beta form, is the most studied of these phytochemicals, and could be involved in the possible cytotoxic effect found in micronucleus test, because it is known to induce apoptosis in many murine and human cancerous cell lines in vitro, even at concentrations considered to be very low (Janezic and Rao, 1992; Awad et al., 2000; Moon et al, 2007; Zhao et al., 2009). Studies with oxidised products of $\beta$-sitosterol in vitro (Maguire et al., 2003; Lea et al., 2004) and in vivo (Abramsson-Zetterberg et al., 2007) revealed neither genotoxic nor mutagenic effects.

In conclusion, through the use of Salmonella/microsome system and of the in vivo assays employed in our work, we can conclude that the leaf and root extracts from C. mollis posses low mutagenic response. Further studies are still required for a better understanding of the biological activities of the extracts of C. mollis, as they are important for scientifically confirming of the popularly proposed effects and for providing greater safety to people using this medicinal plant. However, the preliminary results, as presented for the first time, can be of aid in guiding such investigations, and contribute to the future registration and validation of this phytotherapeutic medicine. 


\section{Acknowledgments}

We wish to thank Rodrigo Juliano Oliveira, of the State University of Londrina (UEL), for his invaluable assistance in the in vivo experiments. We also thank Iuri B. de Barros, of the Department of Chemistry (UEL), for his attention and assistance in relation to the extracts and, A. Leyva for the English language editing of the manuscript.

\section{References}

Abramsson-Zetterberg L, Svensson M and Johnsson L (2007) No evidence of genotoxic effect in vivo of phytosterol oxidation products triols and epoxides. Toxicol Lett 173:132-139.

Awad AB, Downie AC, Fink CS and Kim U (2000) Dietary phytosterol inhibits the growth and metastasis of MDAMB-231 human breast cancer cells grown in SCID mice. Anticancer Res 20:821-824.

Bast A, Chandler RF, Choy PC, Delmulle LM, Gruenwald J, Halkes SBA, Keller K, Koeman JH, Peters P, Przyrembel H, et al. (2002) Botanical health products, positioning and requirements for effective and safe use. Environ Toxicol Pharmacol 12:195-211.

Bernstein L, Kaldor J, McCann J and Pike MC (1982) An empirical approach to the statistical analysis of mutagenesis data from Salmonella test. Mutat Res 97:267-281.

Cota BB, Oliveira AB, Souza-Filho JD and Braga FC (2003) Antimicrobial activity and constituents of Coccoloba acrostichoides. Fitoterapia 74:729-731.

Go SY, Kwon KJ, Park SN and Sheen YY (2007) Genetic toxicity test of emodin by Ames, Micronucleus, Comet assays and microarray analysis showing differential result. J Appl Pharmacol 15:192-198.

Gosh L, Arunachalam G, Murugesan T, Pal M and Saba BP (2002) Studies on the psychopharmacological activities of Rumex nepalensis Spreng root extract in rats and mice. Phytomedicine 9:202-206.

Gu J, Zhang X, Fei Z, Wen A, Qin S, Yi S, Chen Y and Li X (2000) Rhubarb extracts in treating complications of severe cerebral injury. Chin Med J 113:529-531.

Hayashi M, Morita T, Kodama Y, Sofuni T and Ishidate Jr M (1990) The micronucleus assay with mouse peripheral reticulocytes using acridine orange-coated slides. Mutat Res 245:245-249.

Janezic SA and Rao AV (1992) Dose-dependent effects of dietary phytosterols on epithelial cell proliferation of the murine colon. Food Chem Toxicol 30:611-616.

Kobayashi H, Sugiyama C, Morikawa Y, Hayashi M and Sofuni T (1995) A comparison between manual microscopic analysis and computerized image analysis in the single cell gel electrophoresis assay. MMS Commun 3:103-115.

Krishna G and Hayashi M (2000) In vivo rodent micronucleus assay: Protocol, conduct and data interpretation. Mutat Res 455:155-166.

Krivobok S, Seigle-Murandi F, Steiman R, Marzin DR and Betina V (1992) Mutagenicity of substituted anthraquinones in the Ames/Salmonella microsome system. Mutat Res 279:1-8.

Lea LJ, Hepburn PA, Wolfreys AM and Baldrick P (2004) Safety evaluation of phytosterol esters. Part 8. Lack of genotoxicity and subchronic toxicity with phytosterol oxides. Food Chem Toxicol 42:771-783.

Lee N, Choi J, Koo B, Ryu S, Han Y, Lee S and Lee D (2005) Antimutagenicity and cytotoxicity of the constituents from the aerial parts of Rumex acetosa. Biol Pharm Bull 28:2158-2161.

Longo V, Amato G, Salvetti A and Gervasi PG (2000) Heterogenous effects of anthraquinones on drug-metabolizing enzymes in the liver and small intestine of rat. Chem-Biol Int 126:63-77.

Lorenzi H (2002) Coccoloba mollis Casar. (Família Polygonaceae). In: Lorenzi H (ed) Árvores Brasileiras: Manual de Identificação e Cultivo de Plantas Arbóreas Nativas do Brasil, v. 2. Instituto Plantaum, Nova Odessa, pp 293.

Lu M, Hsieh M, Wu C, Cheng H, Hsieh C, Lin Y and Peng W (2007) Ameliorating effect of emodin, a constitute of Polygonatum multiflorum, on cyclohexamide-induced impairment of memory consolidation in rats. J Ethnopharmacol 112:552-556.

Maguire L, Konoplyannikov M, Ford A, Maguire AR and O'Brien NM (2003) Comparison of the cytotoxic effects of B-sitosterol oxides and a cholesterol oxide, 7B-hydroxycholesterol, in cultured mammalian cells. Br J Nutr 90:767775.

Maron DM and Ames BN (1983) Revised methods for the Salmonella mutagenicity test. Mutat Res 113:173-214.

Masuda T, Haraikawa K, Morooka N, Nakano S and Ueno Y (1985) 2-hydroxyemodin, an active metabolite of emodin in the hepatic microsomes of rats. Mutat Res 149:327-332.

Masuda T and Ueno Y (1984) Microsomal transformation of emodin into a direct mutagen. Mutat Res 125:135-144.

Mengs U, Krumbiegel G and Völkner W (1997) Lack of emodin genotoxicity in the mouse micronucleus assay. Mutat Res 393:289-293.

Moon DO, Lee KJ, Choi YH and Kim GY (2007) $\beta$-sitosterol induced apoptosis is mediated by the activation of ERK and the downregulation of Akt in MCA-102 murine fibrosarcome cells. Int Immunopharmacol 7:1044-1053.

Mors WB, Rizzini CT and Pereira NA (2000) Polygonaceae. In: DeFilipps RA (ed) Medicinal Plants of Brazil. Reference Publishing Inc., Chicago, pp 171-174.

Mortelmans K and Zeiger E (2000) The Ames Salmonella/microsome mutagenicity assay. Mutat Res 455:29-60.

Mueller SO and Stopper H (1999) Characterization of the genotoxicity of anthraquinones in mammalian cells. Biochim Biophys Acta 1428:406-414.

Mueller SO, Stopper H and Dekant W (1998) Biotransformation of the anthraquinones emodin and chrysophanol by cytochrome P450 enzymes. Bioactivation to genotoxic metabolites. Drug Metabol Dispos 26:540-546.

Mueller SO, Schmitt M, Dekant W, Stopper H, Schlatter J, Schreirer P and Lutz WK (1999) Occurrence of emodin, chrysophanol and physcion in vegetables, herbs and liquors. Genotoxicity and anti-genotoxicity of the anthraquinones and of the whole plants. Food Chem Toxicol 37:481-491.

Murakami H, Kobayashi J, Masuda T, Morooka N and Ueno Y (1987) Omega-hydroxyemodin, a major hepatic metabolite of emodin in various animals and its mutagenic activity. Mutat Res 180:147-153. 
NTP, National Toxicology Program (2001) NTP toxicology and carcinogenesis studies of emodin (CAS NO. 518-82-1) feed studies in F344/N rats and B6C3F1 mice. Natl Toxicol Program Tech Ser 493:1-278.

Oliveira PES, Santos WS, Conserva LM and Lemos LPR (2008) Constituintes químicos das folhas e do caule de Coccoloba mollis Casaretto (Polygonaceae). Rev Bras Farmacogn 18:713-717 (Abstract in English).

Phillipson JD (2007) Phytochemistry and pharmacognosy. Phytochemistry 68:2960-2972.

Rates SMK (2001) Plants as source of drugs. Toxicon 39:603613.

Sun M, Sakakibara H, Ashida H, Danno G and Kanazawa K (2000) Cytochrome P4501A1-inhibitory action of antimutagenic anthraquinones in medicinal plants and the structure-activity relationship. Biosci Biotechnol Biochem 64:1373-1378.

Tanaka H, Morooka N, Haraikawa K and Ueno Y (1987) Metabolic activation of emodin in the reconstituted cytochrome P-450 system of the hepatic microsomes of rats. Mutat Res 176:165-70.

Tice RR, Agurell E, Anderson D, Burlinson B, Hartmann A, Kobayashi H, Miyamae Y, Rojas E, Ryu J-C and Sasaki YF (2000) Single cell gel/comet assay: Guideline for in vitro and in vivo genetic toxicology testing. Environ $\mathrm{Mol} \mathrm{Mu}-$ tagen 35:206-221.

Tikkanen L, Matsushima T and Natori S (1983) Mutagenicity of anthraquinones in the Salmonella preincubation test. Mutat Res 116:297-304.

Umbuzeiro GA and Vargas VMF (2003) Teste de mutagenicidade com Salmonella typhimurium (Teste de Ames) como indicador de carcinogenicidade em potencial para mamíferos. In: Ribeiro LR, Salvadori DMF and Marques EK (eds) Mutagênese Ambiental. Editora da ULBRA, Porto Alegre, pp 81-112.

Westendorf J, Marquardt H, Poginsky B, Dominiak M, Schmidt J and Marquardt H (1990) Genotoxicity of naturally occurring hydroxyanthraquinones. Mutat Res 240:1-12.

Zhao Y, Chang SKC, Qu G, Li T and Cui H (2009) Beta-sitosterol inhibits cell growth and induces apoptosis in SGC-7901 human stomach cancer cells. J Agric Food Chem 57:52115218.

Zhou S, Koh H, Gao Y, Gong Z and Lee EJD (2004) Herbal bioactivation: The good, the bad and the ugly. Life Sci 74:935-968.

\section{Internet Resources}

Barros IB, Fidelis QC, dos Santos GF, Pinto JP, Faccione M, Tsuboy MSF, Mantovani MS, Braz-Filho R and Ferreira DT (2007) Phytochemistry of root and leaf of Coccoloba mollis. In: Abstracts of First Brazilian Conference on Natural Products. São Pedro, São Paulo, http://dell.nossosite.com.br/bcnp2007/media/pub/abst_book.pdf (November 3, 2007).

Barros IB, Faccione M, Pinto JP, Fidelis QC, Rezende MI, Daniel JFS, Tsuboy MSF, Mantovani MS, Lonni AASG, Ribeiro GS, et al. (2008) Chemical constituents and biological activities from Coccoloba mollis. In: Abstract of $7^{\text {th }}$ Joint Meeting of AFERP, ASP, GA, PSE \& SIF, Athens, Greece. http://www.jointmeeting.2008athens.gr/dwlds/08_abstract.pdf (August 10, 2008).

CNS, Conselho Nacional de Saúde (1997) Resolução no 251, 7/8/1997. http://www. conselho.saude.gov.br/docs/Resolucoes/Reso251.doc (December 6, 2007).

FDA, Food and Drug Administration (1997) Guidance for Industry S2B Genotoxicity: A Standard Battery for Genotoxicity Testing of Pharmaceuticals. http:/www.fda.gov/CDER/GUIDANCE/1856fnl.pdf (December 1, 2007).

OECD, Organization for Economic Co-Operation and Development (2001) Harmonized Integrated Classification System for Human Health and Environmental Hazards of Chemical Substances and Mixtures. http://www.oecd.org/dataoecd/48/51/37182285.pdf (September 7, 2007).

SBMCTA, Sociedade Brasileira de Mutagênese, Carcinogênese e Teratogênese Ambiental (2004) Orientações Básicas de Execução de Testes de Mutagenicidade para Proteção da Saúde Humana e do Meio Ambiente. http://www.sbmcta.org.br/index.php?arq = doc01 (November 12, 2007).

WHO, World Health Organization (2000) General guidelines for methodologies on research and evaluation of traditional medicine. WHO Publications. http://whqlibdoc.who.int/hq/2000/WHO_EDM_TRM_200 0.1.pdf (January 10, 2008).

Associate Editor: Catarina S. Takahashi

License information: This is an open-access article distributed under the terms of the Creative Commons Attribution License, which permits unrestricted use, distribution, and reproduction in any medium, provided the original work is properly cited. 